\title{
Pesticidal activity of Pakistani Bacillus thuringiensis isolates against Helicoverpa armigera (Hubner) and Earias vittella (Lepidoptera: Noctuidae).
}

\author{
${ }^{1}$ Kausar Malik, ${ }^{2}$ Farkhanda Jabeen, ${ }^{3}$ Mir Muhammad Ali Talpur, ${ }^{4}$ Shagufta \\ Andleeb and ${ }^{5}$ Amjad Farooq \\ ${ }^{I}$ Department of Zoology, Lahore College for Women University, Lahore, Pakistan. \\ ${ }^{2,3}$ Former address: National Centre of Excellence in Molecular Biology, University of the Punjab, Lahore, \\ Pakistan.
}

\begin{abstract}
A large number of Bacillus thuringiensis isolates separated from different ecological regions of Pakistan were analysed for pesticidal activity against two lepidopteran cotton insect pests, American bollworm (Helicoverpa armigera and spotted bollworm (Earias vittella). The biological activity of local B.t. isolates demonstrated a wide range of $L C_{50}$ values against both target pests. The most potent isolates $H W 4.4$ and INS2.25 against Helicoverpa armigera showed $L C_{50}$ value of $9 \mathrm{ng} / \mathrm{mg}$ of artificial diet. The Lc50 value of 2ng/mg of artificial diet was exhibited by local B.t. isolates HFZ 11.3, MR 19.1 and MG 2.6 against Earias vittella.
\end{abstract}

Keywords:Pakistani, Bacillus thuringiensis, Earias vittella, Helicoverpa armigera, Isolate, Lepidoptera, Noctuidae,

\section{Introduction}

Microbial control of insect pest of crops using entomopathogens is an ecologically sound pest management strategy. Although insect viruses and fungal pathogens are used as microbial control agents, but Bacillus thuringiensis Berliner (B.t.) appears to has the greatest potential for this purpose.

Bacillus thuringiensis is an aerobic, spore forming, Gram-positive bacterium that synthesizes a crystalline parasporal inclusion composed of one of several proteins known as insecticidal crystal proteins (ICP) or delta-endotoxins during sporulation. These proteins are specifically toxic to insect larvae and are widely used as bioinsecticides against lepidopterans [1,2,3], dipteran [4] and coleopteran pests [5] and certain nematodes and protozoan pathogens [6]. Upon ingestion by susceptible insect larvae, crystalline inclusion are solubilized in the midgut lumen and converted to active toxin by trypsin like proteases. The activated toxins bind to specific receptors on the brush border membrane of midgut columnar cells and insert into the membrane, where they form pores. As a consequence, epithelial midgut cells swell and lyse, causing the larvae to stop feeding and eventually die by septicemia or starvation [7].

Todate more than 231 receptor specific Cry proteins, classified into 28 families and seven cytolytic proteins have been identified which directly bind to phospholipids [8]. And have been proven to be toxic to specific pests.

Lepidoptera specific crystal proteins are the basic crystal proteins. All the genes encoding protoxin active against lepidopteran larvae are grouped into cry1 class, which is further, divided into several subclasses $(\mathrm{A}-\mathrm{H})$. Based on the amino acid identity $(>80 \%)$, the cry1 A genes have been further divided into $1 \mathrm{Aa}, 1 \mathrm{Ab}$, 1Ac. Genes of the cry1 class (cry1 Aa, - Ab, -Ac, etc) encode 130-160 kDa protoxins, which accumulate in the bipyramidal protein crystals during the sporulation of B.t. $[9,10]$.

The cotton bollworm Helicoverpa armigera (Hubner) (Lepidoptera: Noctuidae) and Earias vittella are the most serious pests in many cotton producing cotton producing countries, including Australia, India, China and Pakistan. The larva causes substantial economical losses to legume, fibre, cereal oilseed and vegetable crops. This pest has proven to be difficult to control by conventional means, mainly due to the development of pesticide resistance [11, 12]. Spotted bollworm Earias vitella is also a major pest of cotton, which is a global cash crop. Cotton plays a pivotal role in Pakistan's economy. Pakistan ranks $4^{\text {th }}$ in cotton production and $3^{\text {rd }}$ as an exporter of raw cotton in the world.

Helicoverpa armigera is a cosmopolitan major pest of Pakistani agriculture and cost the sector millions of rupees per year in management and lost production. This cost is rising as the insects become more resistant and as the area of susceptible crops increases. The pest is a problem in a variety of crops and regions in Pakistan. The main crops affected are cotton, chickpea, maize, wheat, sorghum, sunflowers, tomatoes, potato and variety of vegetables and fruits. 
Past successes in chemical control of pests have disrupted many natural control mechanisms. Since most synthetic pesticides are relatively non-selective, they can destroy non target organisms including beneficial predators and parasites of ruinous pests [9]. Most insects of cash crops had also developed resistance to chemical pesticides [13] that permits minor pests to become major ones [9].

Control of Helicoverpa is currently heavily dependent on the use of chemical insecticides. However, resistance to all commercially available insecticides, except the biological insecticide Bacillus thuringiensis (B.t.), has not been detected in H. armigera. Loss of control due to the development of multi-resistant strains has occurred in cotton area. The increasing emergence of resistance problems means there is urgent need for the development of management strategies, which are less dependent on chemical insecticides and or less, conducive to the development of resistance to the control measures used.

Certain Lepidoptera-active B.t. delta- endotoxins fortunately are toxic to both insect pests of cotton. This provides a biological means of pest control than synthetic chemical pesticides. The perceived advantages of biological control are human safety, high pesticidal activity coupled with safety for beneficial organisms and a reduction in chemical load on the environment. In fact, B.t. is at present the most widely used microbial agent for insect control.

The present study was done to evaluate the toxicity of B.t. isolates separated from different ecological regions of Pakistan against the two major pests of cotton crop for their potential use as biopesticide.

\section{Bacterial culture and isolation of crystal proteins}

\section{Material And Method}

The strains of B.t. used in the present study, were very kindly supplied by the Culture Collection Laboratory, Centre of Excellence in Molecular Biology, University of the Punjab, Lahore. These samples were collected from different areas of Pakistan. Most of the strains selected for the study, were isolated from wheat dust, wheat grains, soil dead insects and animal dung. HD73 (positive control) obtained from American type culture collection (ATCC).

Bacillus thuringiensis cultures were streaked on sporulation medium T3 (Tryptone 3g/L, Tryptose $2 \mathrm{~g} / \mathrm{L}$, Yeast extract $1.5 \mathrm{~g} / \mathrm{L}, \mathrm{MnCl}_{2} .2 \mathrm{H}_{2} \mathrm{O} 0.005 \mathrm{~g} / \mathrm{L}, \mathrm{NaH} 2 \mathrm{PO} 46.9 \mathrm{~g} / \mathrm{L}, \mathrm{Na} 2 \mathrm{HPO} 48.9 \mathrm{~g} / \mathrm{L}$ and agar $15 \mathrm{~g} / \mathrm{L}$ ) and incubated at $30^{\circ} \mathrm{C}$ for 3 to 5 days until sporulation took place. Cells were harvested by washing twice with autoclaved distilled water, centrifugation at 7,000 rpm for 10 minutes at $4^{\circ} \mathrm{C}$. The pellet was resuspended in $50 \mathrm{mM}$ sodium carbonate $\mathrm{pH} 9.5$ containing $10 \mathrm{mM}$ ditiothreitol at $37^{\circ} \mathrm{C}$ for overnight. After centrifugation at $7,000 \mathrm{rpm}$ for 10 minutes at $4^{\circ} \mathrm{C}$, the supernatant was collected and the concentration of soluble crystal proteins (protoxins) was quantified by the microassay method of Biorad using bovine serum albumin (Sigma) as a standard. The solubilized protoxin was activated by treating its $20 \mu \mathrm{g}$ with $1 \mu \mathrm{g}$ of trypsin, were mixed well, followed by incubation at $37^{\circ} \mathrm{C}$ for 3 hours.

\section{Insect rearing and toxicity assay}

Helicoverpa armigera and Earias vittella were reared on an artificial diet. Twenty individual mating pairs maintained in glass jars containing $250 \mathrm{~g}$ of diet and covered with muslin cloth. The rearing jars was placed in the insectory set at $30 \pm 1^{\circ} \mathrm{C}$, a photoperiod of $16: 8(\mathrm{~L}: \mathrm{D})$ and a relative humidity of $50 \pm 5$.

Larvicidal test was carried out with $2^{\text {nd }}$ instar of Helicoverpa armigera and Earias vittella by incorporating suspension containing two-fold serial dilutions of activated proteins of B.t. isolates as well as of positive control (HD 73), into the artificial diet and maintained according to the rearing conditions. Negative Control bioassays were performed with solubilization buffer. Thirty larvae were used for each experiment and bioinsecticidal activity was measured in triplicate. Mortality was counted after three days. $\mathbf{L C}_{50}$ as was calculated with probit analysis [14].

\section{Results}

During the present study, different strains of $B . t$. were checked for larvicidal activity against the $2^{\text {nd }}$ instar of Helicoverpa armigera and Earias vittella. Most of the strains were collected from the province of Punjab. The main objective to collect the strains from different areas of country is to cover the heterogeneity exist among the population of B.t. The sources of isolation for most of the strains were soil, dead insect, animal dung, stored grains and their dust (Tables I, II). Bioassay was done with B.t. isolates to screen the most toxic local isolates against target pests.

The most potent isolates HW 4.4 and INS2.25 against Helicoverpa armigera showed $\mathrm{LC}_{50}$ value of $9 \mathrm{ng} / \mathrm{mg}$ of artificial diet (Table I). The Lc50 value of $2 \mathrm{ng} / \mathrm{mg}$ of artificial diet was exhibited by local B.t. isolates HFZ 11.3, MR 19.1 and MG 2.6 against Earias vittella (Table II). 
IV. Tables

Table I; Larvicidal activity of local Bacillus thuringiensis samples collected from different sources and localities, against American bollworm (Helicoverpa armigera).

\begin{tabular}{|l|l|l|l|l|}
\hline S\# & B.t. ISOLATES & COLLECTION PLACE & SOURCE & LC $_{50}$ VALUES \\
\hline 1 & HFZ 11.3 & Hafizabad & Wheat dust & $10.00 \pm 4.51$ \\
2 & NW 4.12 & Narowal & Soil & $19.88 \pm 3.44$ \\
3 & SL 8.10 & Sialkot & Wheat husk & $86.2 \pm 3.51$ \\
4 & MUL 26.1 & Multan & Cow dung & $49.52 \pm 3.71$ \\
5 & CHN 5.3 & Chiwinda & Wheat dust & $25.27 \pm 4.27$ \\
6 & Gu 1.5 & Gujranwala & Wheat dust & $31.87 \pm 17.32$ \\
7 & GRT 39.1 & Gujrat & Animal dung & $169.06 \pm 3.67$ \\
8 & HW 4.4 & Punjab & Soil & $9.34 \pm 4.53$ \\
9 & INS 1.13 & Dead Insect & Dead Insect & $768.96 \pm 4.19$ \\
10 & INS 2.25 & Dead Insect & Dead Insect & $9.02 \pm 4.71$ \\
\hline
\end{tabular}

Table II; Toxicity of selected local Bacillus thuringiensis isolates against spotted bollworm (Earias vittella).

\begin{tabular}{|l|l|l|l|l|}
\hline S\# & B.t. ISOLATES & COLLECTION PLACE & SOURCE & LC $_{50}$ VALUES \\
\hline 1 & HFZ 24.8 & Hafizabad & Wheat dust & $4.97 \pm 4.37$ \\
2 & NW 25.1 & Narowal & Soil & $70.33 \pm 5.27$ \\
3 & SL 62.3 & Sialkot & Wheat husk & $80.04 \pm 2.26$ \\
4 & MUL 27.6 & Multan & Soil & $3.75 \pm 4.80$ \\
5 & MR 19.1 & MuridKe & Soil & $2.34 \pm 5.06$ \\
6 & MG 2.6 & Punjab & Soil & $2.40 \pm 5.24$ \\
7 & GRT 44.5 & Gujrat & Animal dung & $7.11 \pm 4.24$ \\
8 & MUL 26.1 & Multan & Cow dung & $94.71 \pm 2.27$ \\
9 & HFZ 11.3 & Hafizabad & Wheat dust & $2.39 \pm 5.28$ \\
10 & HD 73 & ATCC & Soil & $72.02 \pm 3.96$ \\
\hline
\end{tabular}

\section{Discussion}

In this study, B.t. sources were soil, animal dung, grain dust and dead insects. Although B.t. was found in all the samples but its occurrence in the soil samples was found to be relatively high compared to other types of samples. This observation is in disagreement with those of DecLucca and Theunis $[15,16]$ who reported 5\%, $14 \%$ and $16 \%$ incidence of B.t. positive soil samples respectively. It appears, the isolation of B.t. from soil is variably successful with the range from 3-85\% [17] and from 22-50\% [18, 19]. B.t. is a common member of soil microflora. After soil, a particularly good source of B.t. has been found to be stored product material. Theunis [16] have reported the grain dust to be the richest source with $63 \%$ samples containing B.t. due to low level of humidity and ultraviolet rays in grain mills favour the B.t. spores. However, $80 \%$ local isolates of B.t. were isolated from soil samples, $12 \%$ were from animal waste, while $8 \%$ were from wheat straw sample, reported by [20].

It has been reported that different B.t. isolates can have a large variation in their biological activity against same species and a given isolate may be very active against one species and inactive against others [21]. This amazing variability and complexity of host range in lepidopteran-active strains may be the result of multiple cry genes encoding a variety of different protoxins [22]. Relative potency of Cry proteins can be influenced with different factors, a) the origin of toxin (B.t. isolate), b) the expression level of different multigene products, c) solubility and stability of toxins in the midgut of target larvae and, d) the natural stability of host to toxin [23]. Biotoxicity assay results with local B.t. isolates, did not show the same levels of toxicity. The possible explanation could be that perhaps isolates have different expression levels of different Cry toxin protein in their crystal complex. Higher activity in certain isolates could also be attributed to synergism between different toxins as reported in [24] when the same isolates toxicities were checked against rice pests.

\section{Conclusion}

The results obtained in the present investigation appear to be important from the insect resistance and integrated pest management points of view.

Control of Helicoverpa is currently heavily dependent on the use of chemical insecticides. However, resistance to all commercially available insecticides, except the biological insecticide Bacillus thuringiensis (B.t.), has not been detected in $H$. armigera. Loss of control due to the development of multi-resistant strains has occurred in cotton area. The increasing emergence of resistance problems means there is urgent need for the 
development of management strategies, which are less dependent on chemical insecticides and or less, conducive to the development of resistance to the control measures used. Concern about environmental pollution, resistance to pesticides, residues in food and biodiversity make new and less insecticide-dependent strategies and technologies crucial in combating major pests to secure sufficient food for a rapidly growing world population.

\section{References}

[1] A. I. Aronson, W. Beckman, and P. Dunn, Bacillus thuringiensis and related insect pathogens Microbiol Rev., 50, $1986,1-24$.

[2] H. Hofte, \& H. R. Whiteley, Insecticidal crystal proteins of Bacillus thuringiensis. Microbiol. Rev. 53, 1989, $242-255$.

[3] S. C. MacIntosh, G. M. Kishore, F. J. Perlak, P. G. Marrone, T. B. Stone, S. R. Sims, R. L. Fuchs, Potentiation of Bacillus thuringiensis insecticidal activity by serine protease inhibitors. Journal of Agricultural and Food Chemistry. 38, $1990,1145-1152$.

[4] Goldberg, L. J., and Margalit, J., (1977) A bacterial spore demonstrating rapid larvicidal activity against Anopheles serengetti, Uranotaenia unguiculta, Culex univittatus, Aedes aegypti and Culex pipiens. Mosq. News. 37, 355-358.

[5] A. Krieg, A. Huger, G. Langenbruch, and W. Schetter, Bacillus.thuringiensis var tenebrionis; a new pathotype effective against larvae of coleoptera. J. appl. Ent., 96, 1983, 500-508.

[6] J. S. Feitelson, J. Payne, \& L. Kim, Bacillus thuringiensis; Insects and beyond. Bio/Technology. 10, 1992, 271-275.

[7] B. H. Knowles, Mechanism of action of Bacillus.thuringiensis Inectisidal $\delta$-endotoxin. Adv. Insect Physiol. 24, 1994, 275-308.

[8] (http:/www.lifesci.sussex.ac.uk/home/Neil_Crickmore/Bt 2007)

[9] L. A. Bulla, L. I. JR., Davidson, K. J. Kramer, and B. L. Jones, Purification of insecticidal toxin from the parasporal crystal of Bacillus thuringiensis subsp. Kurstaki. Biochemical and Biophysical Research communications 91, 1979, 1123-1130.

[10] L. Chang, R. Grant, A. Aronson, Regulation of the Packaging of Bacillus thuringiensis delta-endotoxins into Inclusions. Appl Environ Microbiol 67, 2001, 5032-5036.

[11] E. Estebanez-Perpina, A. Bayes, J. Vendrell, M. A. Jongsma, D. P. Bown, J. A. Gatehouse, R. Huber, W. Bode, F. X. Aviles, D. Reverter, Crystal structure of a novel mid-gut procarboxypeptidase from the cotton pest Helicoverpa armigera. J. Mol. Biol. 313, 2001, 629-638.

[12] K. R. Krathi, D. R. Jadhav, R. R. Wanjari, S. S. Ali, D. Russel, Pyrethnoid resistance and mechanism of resistance in field strains of Helicoverpa armigera (Lepidoptera: Noctuidae). J. Econ. Entomol. 94, 2001, 253-263.

[13] G. P. Georghiou, Overview of insecticide resistance. Pp. 18-41, in managing resistance to agrochemicals. Eds. M.B. Green, H.M. LeBaron and W.K. Moberg. American Chemical Society, Washington, D.C. USA 1990.

[14] M. Raymond, Log-probit analysis basic programme of microcomputer.Cohiers ORSTOM Serie. Entomology Medicale et Parasitologie 23, 1985, 117-121.

[15] A. J. DeLucca, J. G. Simonson, and A. D. Larson, Bacillus thuringiensis distribution in soil in the United States. Can. J. Microbiol. $27,1981,865-870$.

[16] W. Theunis, R. M. Aguda, W. T. Cruz, C. Decock, M. Peferoen, B. Lambert, D. G. Bottrell, F. L. Gould, J. A. Litsinger, and M. B. Cohan, Bacillus thuringiensis isolates from the Philippines:habitat distribution, delta-endotoxin, diversty and toxicity to rice stem borers (Lapidoptra:Pyralidae). Bull. entomol. Res. 88, 1998, 335-342.

[17] P.A.W. Martin, and R. S. Travers, Worldwide abundance and distribution of Bacillus thuringiensis isolates. Appl. environ. Microbial. 55, 1989, 2437-2442.

[18] C. N. Chilcott, and P. J. Wigley, Isolation and toxicity of Bacillus thuringiensis from soil and insect habitats in Newzeland. J. Inverb. Pathol. 61, 1993, 244-247.

[19] M. Ohba, N. Wasano, and E. Mizuki, Bacillus thuringiensis soil populations naturally occurring in the Ryukyus, a subtropic region of Japan. Microbiol. Res. 155: 2000, 17

[20] D. A. Bukhari, and A. R. Shakoori, Isolation and molecular characterization of cry4 harbouring Bacillus thuringiensis isolates from Pakistan and mosquitocidal activity of their spores and total Proteins. Pak. J. Zool. 42(1), 2010, 1-15.

[21] P. Jarrett, and H. D. Burges, Effect of bacterial variations on the susceptibility of the greater wax moth, Galleria mellonella to Bacillus thuringiensis and its significance in the classification of the bacterium. Entomol. Exptl. Appl. 31, 1982, 346-352

[22] P. Jarrett, Potency factors in the delta-endotoxin of Bacillus thuringiensis var.aizawai and the significance of plasmids in their control. J. Appl. Bacteriol. 58, 1985, 437-448.

[23] A. I. Aronson, E. S. Hans, W. McGaughey, and D. Johnson, The solubility of inclusion proteins from Bacillus thuringiensis is independent upon protoxin composition and is a factor in toxicity to insects. Appl. Environ. Microbiol. 57, 1994, 981-986.

[24] S. Karim, K. Malik. U. Zafar, and S. Riazuddin, Evaluation of Pakistanian Bacillus thuringiensis isolates against Scirpophaga incertulas and Cnaphalocrocis medinalis. Journal of Asia-Pacific Entomology 2(1), 1999, 61-67. 